Tér és Társadalom 23. évf. 2009/2. 225-235. p.

\title{
EURÓPA TÉRKÉPE ÁTALAKUL A LÉGIKÖZLEKEDÉS HATÁSÁRA
}

\section{(Map of Europe has been Changed by Air Transport)}

\section{LEGEZA ENIKÖ - TÖRÖK ÁDÁM}

Kulcsszavak:

légi személyközlekedés időrövidülés távolság függvény

A repülés iránti vágy nagyon régóta megmozgatja az emberek képzeletét. A görög mondabeli Ikarosznak is az volt a legföbb álma, hogy a madarakkal együtt szárnyalhasson, ám az ö próbálkozásai kezdetektól fogva kudarcra voltak itélve. Cikkünk célja a légi személy közlekedés pozitiv hatásainak feltérképezése, azon belül is az utazási idö rövidülésének matematikai modellezése, megjelenitése. A repterek közötti tóvolság helyett az utazási időt használva ủj elérhetöségi rangsort kapunk, amit ábrázolva Európa térképe jelentösen átformálódik.

\section{Bevezetés}

Az észak karolinai Kitty Hawk közelében fekvő Kill Devil Hill-en emelkedett fel a levegöbe az első levegőnél nehezebb légi jármủ, 1903-ban, a Wright fivéreknek köszönhetően $(1 . a ́ b r a)$. A repülés iránti vágy azonban már jóval régebben is megmozgatta az emberek képzeletét.

\author{
1. ÁBRA \\ A Wright fivérek elsö repülése \\ (First Fly of the Wright Brothers)
}

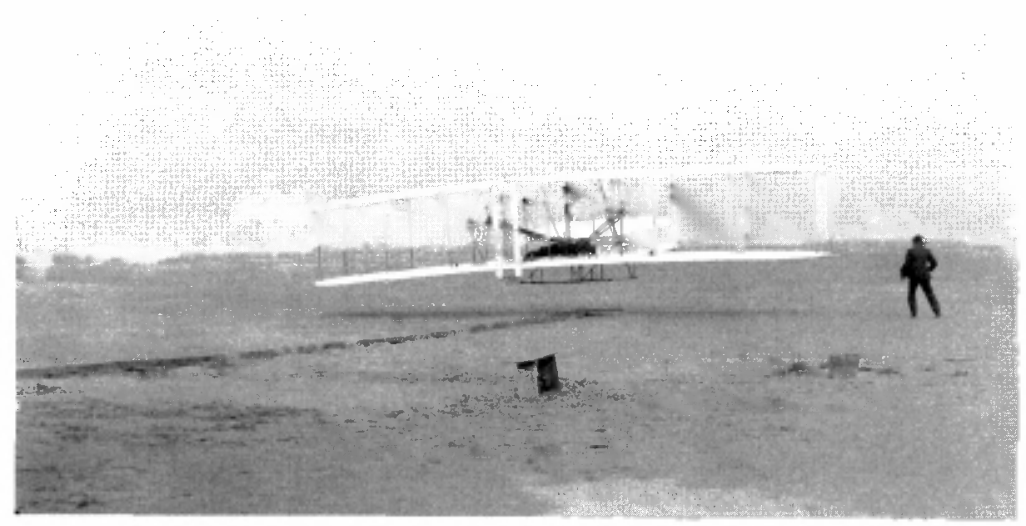

Forrás: Amerikai Egyesült Államok Kongresszusi Könyvtár ID cph.3a53266. 
A világ első, hajtott és embert szállító léghajója Henry Giffard-nak köszönhető, aki gözgépével hajtott léghajójával 1852. szeptember 24-én emelkedett a levegőbe a párizsi Hippodromé lóversenypálya mellől. A repülés fejlődésében 1909-ben Louis Blériot-val nagy lépés történt, mindenki számára bebizonyitotta a repülőgép gyakorlati használhatóságát, átrepülve a kontinensröl Angliába. A légi közlekedés egyértelmủ előnye, a nagy sebesség csak nagy utazási távolságok esetén érvényesül igazán. 1927-ben újabb fordulóponthoz érkezett a repülés történelme, amikor az amerikai Charles Lindbergh külön az erre a célra épített „Spirit of St. Louis” nevű gépével sikeresen landolt Párizsban, az Atlanti-óceán átrepülését követően, mely több mint 33 órát vett igénybe.

A mai viszonylatban is modernnek mondható elsö utasszállító repülögép az amerikai Douglas DC-3-as volt (2. ábra), első repülése 1935-ben valósult meg.

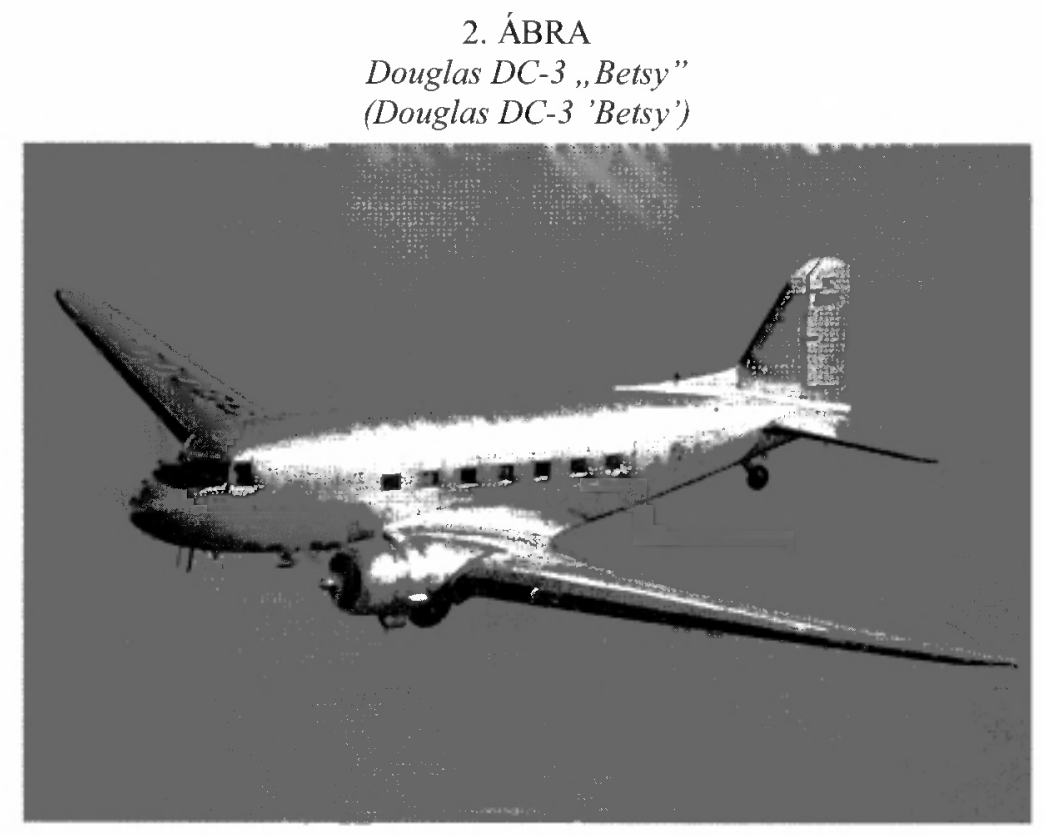

Forrás: Northwest Franklin County Historical Society Library.

A háború végeztével, a hatalmas katonai légi flották kihasználatlanok maradtak, így kézenfekvő lépés volt azok alkalmazása a polgári repülésben. A gyors vadászgépek a postai küldeményeket rövid időn belül jutatták el a célba, a nehézbombázók pedig némi átalakítással ideálisnak túntek emberek szállítására. Ezek a gépek a folyamatos fejlödési igényeknek egyre kevésbé tudtak megfelelni, így egyre több korszerü, áramvonalasabb, könnyebb gép jelent meg, amelyek kényelmesebbek is lettek.

Az első sugárhajtású utasszállító repülőgépet az angolok kezdték üzemeltetni, mely 1952-ben állt szolgálatba menetrendszerü közlekedésével (3. ábra). 


\section{3. ÁBRA}

DH-106 Comet 1, a világ elsö jet utasszállitója

(DH-106 Comet 1, First Passenger Carrier Jet)

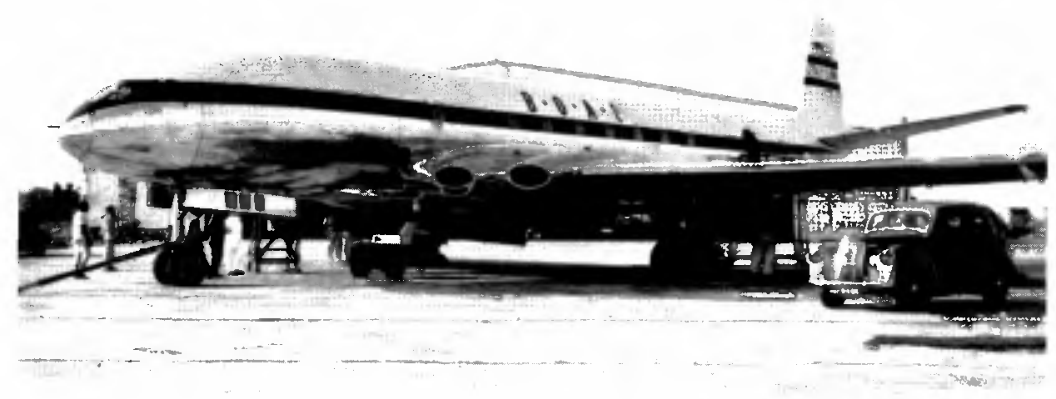

Forrás: Davies-Birtles (1999).

Repülési magasságának és sebességének köszönhetően az időjárási körülmények befolyásoló hatását is mérsékelte, ami az utazási időt megközelítően felére csökkentette.

A technológiai fejlödés következő példảja már a hangsebesség két és félszeresével repülő angol-francia együttmüködéssel készült „Concorde” (4. ábra). Az Atlantióceán két partja között elképesztő, 3,5 órás repülési időtartammal létesített kapcsolatot. Első repülése már 1969-ben megtörtént, 2003-ban viszont kivonták a forgalomból. 30 éves szolgálati ideje alatt egyedülállóan sok csúcsot állított fel.

\section{4. ÁBRA \\ Concorde \\ (Concorde)}

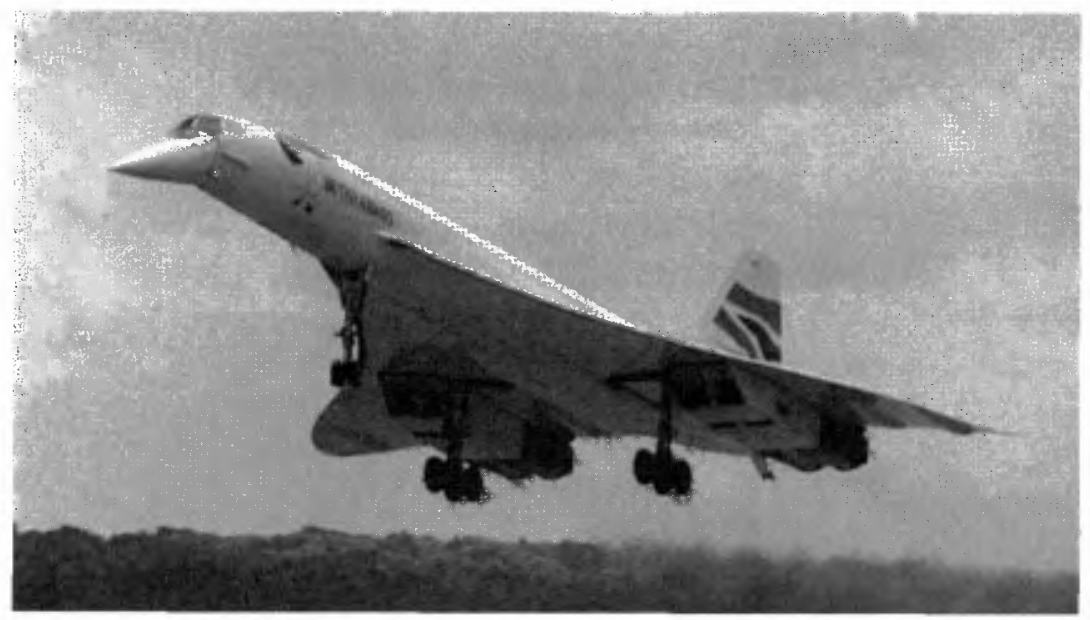

Forrás: British Airways. 
Legeza Enikő - Török Ádám : Európa térképe átalakul a légiközlekedés hatására.

Tér és Társadalom 23. évf. 2009/2. 225-235. p.

Napjainkban egyelöre más irányát láthatjuk a fejlődésnek, mely a korszerü gazdasági, kereskedelmi és egyéb követelményeket is szem elött tartó óriásgépek megjelenését jelenti. Példaként említhetjük az Airbus repülőgépgyár kétszintes gigászát, az A380-as repülőgépet (5. ábra), melynek rendelésre történő sorozatgyártása folyamatban van.

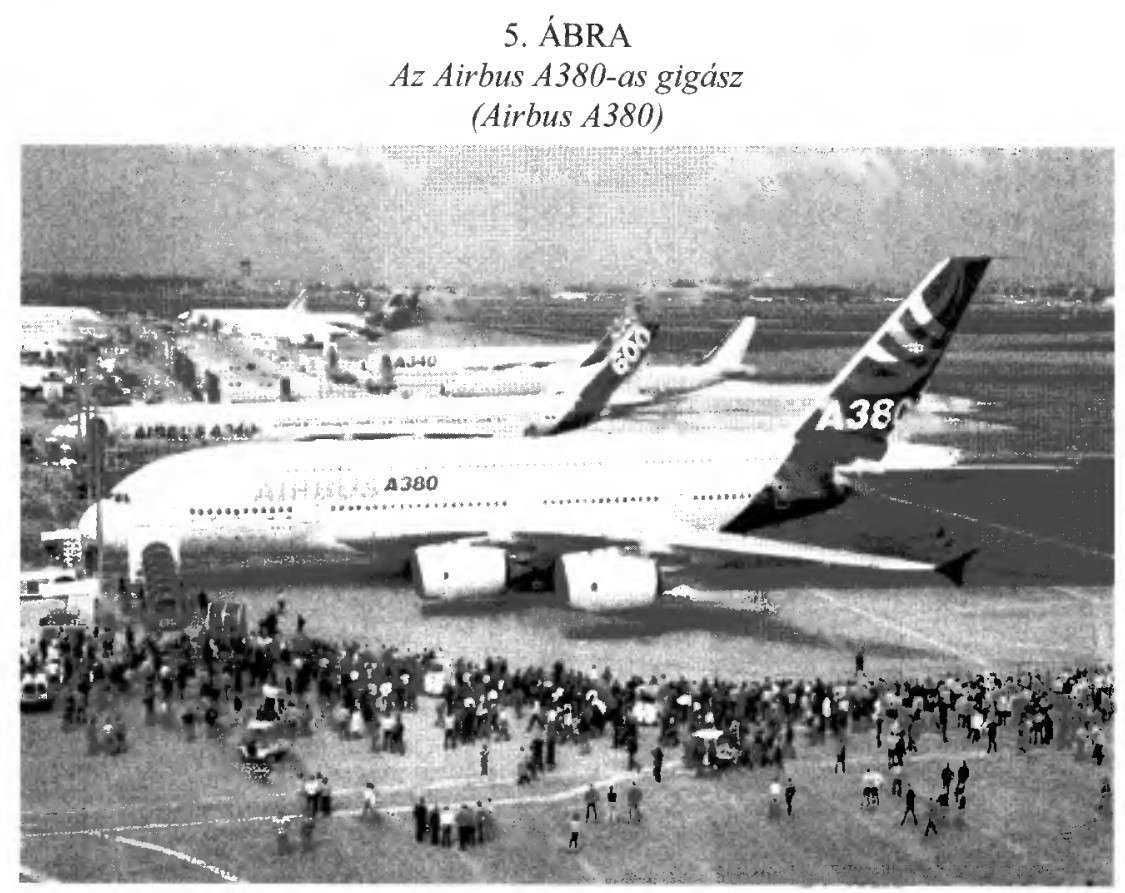

Forrás: Flight International.

\section{A légi forgalom hatása}

A közlekedés és azon belül a légi közlekedés pozitív hatással van a nemzetgazdasági folyamatokra, bővül a fogyasztás és a fogyasztók köre, növekszik a mobilitás és ezáltal az életszínvonal, pozitív hatással lehet a munkaerö-piacra és az ipari és kereskedelmi folyamatokra. Az infrastruktúra-beruházások kedvező hatásai is az érintetteknél pozitív hatásként jelentkezhetnek, hiszen az adott környéken található boltok, áruházak jelentős árbevétel növekedéssel számolhatnak, valamint az ott található ingatlanok értéke is növekedhet. Ezeknek a pozitív hatásoknak a megfelelö monetarizálása akár jelentős részét is fedezheti a beruházásoknak.

A légi közlekedési fejlesztési és üzemeltetési tevékenységek nemzetgazdasági szintủ értékelésekor természetesen nem szabad megfeledkezni a negatív (externális) hatások számbavételéröl sem. A légi közlekedés ugyanis fajlagosan (közlekedési teljesítményre vetítve) általában a legmagasabb társadalmi költségủ áru- és személyszállítási módok 
Legeza Enikő - Török Ádám : Európa térképe átalakul a légiközlekedés hatására.

Tér és Társadalom 23. évf. 2009/2. 225-235. p.

TÉT XXIII. évf. 2009 @ 2

Kitekintö

229

közé tartozik (igaz, magas a szolgáltatási színvonal is) (Bokor-Tánczos 2003). Ezért itt bármilyen hatékonyságnövelö intézkedés számottevő megtakarítást hozhat.

Nehéz elképzelni ugyanakkor olyan élénk gazdasági növekedést, amely képes álláshelyeket és jólétet teremteni a belső piac és a globalizálódott kereskedelem öszszes előnyének kihasználását lehetôvé tevő, hatékony közlekedési rendszer nélkül. Annak dacára, hogy a 21. század kezdetén az információs társadalom és a virtuális kereskedelem korába lépünk, semmi sem történt, ami miatt csökkenne az utazások iránti igény; sőt, ennek az ellenkezője igaz. Az Interneten ma bárki bárkivel kapcsolatba léphet és árukat rendelhet a távolból, ugyanakkor még mindig élvezheti annak előnyeit is, hogy személyesen ellátogathat más helyekre, termékeket nézegethet és válogathat, vagy találkozhat más emberekkel, kultúrákkal és tájakkal (Legeza 2001). Az információs technológiák azonban arra is bizonyítékul szolgálnak, hogy a távmunka vagy a távszolgáltatások megkönnyítésével néha elősegíthetik a fizikai szállítás iránti igények csökkenését, vagy épp ellenkező hatással bỉrnak, gondoljunk csak az internetes jegyváltás és check-in lehetöségére a légi közlekedés esetében, mely kényelmi szolgáltatásként megkönnyíti a légi utasok teendöit.

A légi közlekedésben alkalmazottak relatíve jól fizetettek, kultúrált és fegyelmezett munkát végeznek. Sok esetben dinasztiák követik egymást ebben az iparágban is. Gyakran a lakás, családi ház is a repülőtér közelében van. Jelentős az a szekunder kapcsolat is például, hogy a repülőtérre szállító taxik, ingajáratok jövedelmüknek egy részét innen szerzik. Ez a gyakorlatban azt jelenti, hogy 1 repülötéri állás további (egynél több) másodlagos állást kreál, illetve 1 repülötéri állás megszüntetése a többi ágazatban 1-nél nagyobb számú állást érint. Tehát a repülőterek az ország infrastruktúrájának fontos részét alkotják. A légi közlekedés számtalan iparággal van kapcsolatban megrendelései révén, így a GDP-hez ilyen módon hozzájárul. A légi közlekedés jelentősen csökkenti az utazási időt. Cikkünk célja egy olyan térkép megalkotása, mely szokatlan módon nem az egyes földrajzi helyek, városok közötti távolságot hivatott szemléltetni, hanem az utazási időt. A légi közlekedés által, 12 európai várost figyelembe véve, az érintett városok között a térkép megmutatja mennyire kerülhetnek közel, vagy távolodhatnak el egymástól jól ismert metropoliszok az utazási idó függvényében; Európa térképe ,átalakul”.

Az 1. táblázatból jól látható, hogy az Európában lévő városok repülőterei által lebonyolított éves forgalom jelentős mértékủ. Világviszonylatban is elökelő helyet foglalnak el az európai városok ezen eredményeikkel. A légi közlekedés sajátosságai miatt, két város között az oda-vissza repült útvonal hossza és időtartama is különbözhet egymástól. A különbözetböl eredő hiba nem szignifikáns, ezért a továbbiakban az átlagos távolságot és időt használtuk. A földrajzi távolság helyett a repülóut átlagos hosszát vettük alapul. A navigátor az adott nagytávolsági viszonylatokban az ortodróma ${ }^{1}$ és a loxodróma ${ }^{2}$ közötti „kompromisszumként” jelöli ki az útvonalat. A loxodrómához kapcsolódó ortodróma ugyanazon két földrajzi pont között a legrövidebb útvonal. A loxodróma a sík Föld térképen egyenessé fajul. A két légikikötő közötti loxodrómikus ív sík térképen egyszerủen e két repülőtér közötti egyenes. Mivel azonban a loxodrómikus távolságok a gömbön tetemesen nagyobbak, mint a 
Legeza Enikö - Török Ádám : Európa térképe átalakul a légiközlekedés hatására.

Tér és Társadalom 23. évf. 2009/2. 225-235. p.

legrövidebb gömbi távolságok, újabban a növekvő forgalom miatt mindinkább elhagyják a loxodrómán való repülést, és áttérnek a legnagyobb gömbi kör mentén történö repülésre.

\section{TÁBLÁZAT}

Az időtérképen feltüntetett városok 2007. évi forgalmi adatai (Traffic Data of Investigated Airports in 2007)

\begin{tabular}{|c|c|c|c|}
\hline $\begin{array}{l}\text { Város } \\
\text { neve }\end{array}$ & $\begin{array}{c}\text { Repülötér } \\
\text { neve }\end{array}$ & $\begin{array}{l}\text { Összes utas } \\
\text { száma }\end{array}$ & $\begin{array}{c}\text { Rang } \\
\text { Európában* }\end{array}$ \\
\hline Amszterdam & Schiphol & 47429741 & 5. \\
\hline Bécs & Schwehat & 18768468 & 20. \\
\hline Berlin & Tegel & 13357741 & 30. \\
\hline Brüsszel & $\begin{array}{l}\text { Brussels } \\
\text { International }\end{array}$ & 17838214 & 23. \\
\hline Budapest & Ferihegy & 8581071 & 48. \\
\hline Frankfurt & Frankfurt/Main & 54161856 & 3. \\
\hline London & Heathrow & 67056228 & 1. \\
\hline Madrid & $\begin{array}{l}\text { Barajas } \\
\text { International }\end{array}$ & 50823105 & 4. \\
\hline München & $\begin{array}{l}\text { Francz Joseph } \\
\text { Strauss }\end{array}$ & 34530593 & 7. \\
\hline Párizs & $\begin{array}{l}\text { Charles de } \\
\text { Gaulle }\end{array}$ & 60851998 & 2. \\
\hline Stockholm & Arlanda & 17968023 & 22. \\
\hline Zürich & Kloten & 20682094 & 18. \\
\hline
\end{tabular}

* 456 európai repülótér éves utasforgalma alapján.

Forrás: ACI-EUROPE AIRPORT TRAFFIC STATISTICS (2007).

Az utazási idő és távolság hányadosaként megkaphatjuk az átlagos utazási sebességet. A fenti táblázatból látható, hogy az átlagos repülési sebesség nem állandó, tehát az utazási idő nem lineáris leképezése a földrajzi távolságnak (2. táblázat). Köztudott, hogy egymástól nagy távolságra levő repülóterek között az átlagos utazási sebesség nagyobb, mint az egymáshoz közeli repülöterek között, mert az út eleji és végi lassító manőverek nagyjából minden esetben azonos időigényủek. Ezzel magyarázatot nyert a repülési idő s távolság dichotómiájának problémája. 
Legeza Enikő - Török Ádám : Európa térképe átalakul a légiközlekedés hatására.

Tér és Társadalom 23. évf. 2009/2. 225-235. p.

TÉT XXIII. évf. 2009 @ 2

Kitekintö

231

2. TÁBLÁZAT

Európai légikikötők közötti távolságok és repülési időtartamok

(Distance and Travel Time between Investigated Airports)

\begin{tabular}{|c|c|c|c|c|c|c|c|c|c|c|c|c|}
\hline $\begin{array}{l}\text { Távolság } \\
\text { [km] } \\
\backslash \\
\text { Idótartam } \\
\text { [óra:perc] }\end{array}$ & 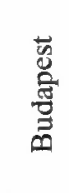 & 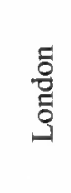 & . & $\bigcup_{\mathscr{W}}^{\infty}$ & 寻 & 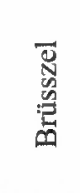 & 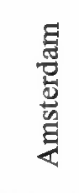 & $\begin{array}{l}\frac{D}{E} \\
\frac{\pi}{J} \\
\Sigma\end{array}$ & $\begin{array}{l}\frac{E}{0} \\
\frac{E}{d} \\
\frac{D}{0} \\
\frac{D}{n}\end{array}$ & 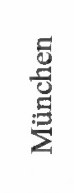 & 窇 & 点 \\
\hline Budapest & & 1500 & 1300 & 250 & 700 & 1200 & 1200 & 2000 & 1400 & 600 & 800 & 850 \\
\hline London & $2: 30$ & & 350 & 1300 & 950 & 350 & 400 & 1300 & 1450 & 950 & 800 & 650 \\
\hline Párizs & $2: 15$ & $2: 20$ & & 1050 & 900 & 300 & 450 & 1100 & 1550 & 700 & 500 & 450 \\
\hline Bécs & $1: 00$ & $2: 30$ & $2: 10$ & & 550 & 950 & 950 & 1850 & 1250 & 400 & 600 & 650 \\
\hline Berlin & $1: 45$ & $2: 00$ & 1.45 & 120 & & 700 & 600 & 1900 & 800 & 500 & 700 & 450 \\
\hline Brïsszel & $2: 00$ & $1: 15$ & $1: 00$ & $1: 50$ & $1: 20$ & & 200 & 1350 & 1300 & 600 & 500 & 300 \\
\hline Amszterdam & $2: 00$ & 120 & $1: 20$ & $4: 05$ & $2: 10$ & $0: 50$ & & 1500 & 1150 & 700 & 650 & 400 \\
\hline Madrid & $3: 10$ & $2: 30$ & $2: 10$ & $6: 00^{*}$ & 3:00 & $2: 40$ & $2: 25^{*}$ & & 2600 & 1500 & 1250 & 1450 \\
\hline Stockholm & $2: 10$ & $2: 40$ & $2: 35$ & $4: 30^{*}$ & 130 & $2: 15$ & $2: 10$ & 4.00 & & 1350 & 1500 & 1250 \\
\hline München & $1: 20$ & $2: 00$ & $1: 40$ & $1: 05$ & 1:10 & $1: 20$ & $1: 30$ & $2: 35$ & $2: 10$ & & 250 & 300 \\
\hline Zuirich & 1.45 & $1: 30$ & $1: 20$ & $2: 35$ & $1: 30$ & $1: 10$ & $2: 35$ & $2: 10$ & $2: 25$ & 1,00 & & 300 \\
\hline Frankfurt & 1:45 & $1: 40$ & $1: 15$ & $1: 35$ & $1: 10$ & 1:00 & $1: 40$ & $2: 40$ & $2: 10$ & $1: 10$ & $1: 15$ & \\
\hline
\end{tabular}

Forrás: Saját szerkesztés.

\section{Az utazási idő matematikai modellezése}

A légi közlekedés eredetủ utazási idő rövidülés elemzésére és megjelenítésére az európai légikikötők közötti távolságokra és utazási időre vonatkozó adatok szolgáltak alapul (2. táblázat). Az utazási idő prezentálja egy közlekedési rendszer felhasználó központú hatékonyságát (Giannopoulos-Aifadopoulou-Torok 2008). A gráf csomópontok és rajtuk értelmezett összeköttetések (élek) halmaza (Reinhard 2005). Esetünkben a légikikötők a gráf csúcspontjai, az utazási időkkel reprezentált repülỏutak a gráf élei. Alapértelmezésben a gráf irányítatlan, azaz nem teszünk különbséget „A-ból B-be”, illetve „B-ből A-ba” menő élek között. Szintén alapértelmezésben, a gráf csúcsai címkézettek, azaz meg lehet különböztetni őket.

A hagyományos euklideszi geometria pontjai modellezhetők valós számok rendezett n-eseivel, azaz n-dimenziós vektorokkal. Például a sík egy pontja megadható egy $\mathrm{A}=\left(\mathrm{x}_{1}, \mathrm{y}_{1}\right)$ számpárral. Az euklédeszi térben két pont távolságát az euklédeszi távolság ( 2 normás távolság) adja meg.

1) $d_{A B}=\sqrt{\left(\sum_{i=1}^{n}\left|a_{i}-b_{i}\right|^{2}\right)}$ 
Például az euklideszi síkban $A\left(a_{1}, a_{2}\right)$ koordinátájú pont és $B\left(b_{1}, b_{2}\right)$ koordinátájú pont Descartes-módra koordinátázott távolsága:

2) $\mathrm{d}_{\mathrm{AB}}=\sqrt{\left(\mathrm{x}_{1}-\mathrm{y}_{1}\right)^{2}+\left(\mathrm{x}_{2}-\mathrm{y}_{2}\right)^{2}}$

Ez a két pont közötti legrövidebb egyenes távolságot adja meg. Ha Európa léptékü légikikötơk közötti eljutási időt reprezentáló modellt építünk, akkor a fent 2) említett távolság nem alkalmazható, mert a légi közlekedési folyosók illetve utazási idők nem szükségszerủen reprezentálják a legrövidebb utat. Az utazási idő megmutatja hogy i és j légikikötő között mekkora a repülési idö. Cikkünkben a fel- és leszállás, valamint a repülőtérre történő kijutás és a repülötér elhagyásának időszükségletével nem foglalkozunk (Kövári 2001).

Megmutatható, hogy az utazási idő is viselkedhet matematikai értelemben távolságként, és így az utazási időkből kialakítható egy szimmetrikus távolság mátrix:

$$
\text { 3) } \underline{\underline{D}}=\left|\begin{array}{ccc}
0 & d_{1 j} & d_{1 m} \\
d_{i 1} & 0 & d_{i m} \\
d_{m l} & d_{j m} & 0
\end{array}\right|
$$

ahol:

D szimmetrikus, $\mathrm{m} \times \mathrm{m}$ négyzetes ,távolság mátrix”

$\mathrm{d}_{\mathrm{ij}} \mathrm{i}$ és j légikikötö közötti utazási idő

A távolság mátrix szimmetrikus, mert feltétezzük, hogy $\mathrm{d}_{\mathrm{ij}}=\mathrm{d}_{\mathrm{ji}}$ és, ha $\mathrm{i}=\mathrm{j}$, akkor $\mathrm{d}_{\mathrm{ij}}=0$. Ahhoz, hogy az utazási időkből felépithessük a gráfot, a légikikötők egymáshoz viszonyított relatív koordinátáit használtuk fel.

4)

$\underline{D}=\left|\begin{array}{ccc}0 & \left(\sqrt{\left(x_{j}-x_{1}\right)^{2}+\left(y_{j}-y_{1}\right)^{2}}\right) & \left(\sqrt{\left(x_{m}-x_{1}\right)^{2}+\left(y_{m}-y_{1}\right)^{2}}\right) \\ \left(\sqrt{\left(x_{1}-x_{i}\right)^{2}+\left(y_{1}-y_{j}\right)^{2}}\right) & 0 & \left(\sqrt{\left(x_{m}-x_{i}\right)^{2}+\left(y_{m}-y_{i}\right)^{2}}\right) \\ \left(\sqrt{\left(x_{1}-x_{m}\right)^{2}+\left(y_{i}-y_{m}\right)^{2}}\right) & \left(\sqrt{\left(x_{j}-x_{m}\right)^{2}+\left(y_{j}-y_{m}\right)^{2}}\right) & 0\end{array}\right|$

Ellenörzésként az így kapott relatív koordinátákból számított utazási időket hasonlitottuk össze a megfigyelt utazási időkkel. A megfigyelt és számított utazási idők öszszehasonlításához definiáltuk a $\varphi$ transzformáció jóságát meghatározó függvényt.

5) $\varphi=\sum_{i=1}^{m}\left[d_{i j}-f\left(\delta_{i j}\right)\right]^{2}$

ahol:

$\mathrm{d}_{\mathrm{ij}}$ : a számított utazási idő

$\delta_{\mathrm{ij}}$ : a megfigyelt utazási idő

$\mathrm{f}\left(\delta_{\mathrm{ij}}\right)$ : a megfigyelt utazási idők (távolságok) nem metrikus, monoton transzformációja

Esetünkben $\varphi_{\text {légi }}=0,22$ (minél kisebb a szám, annál jobban képezi le a gráf az utazási időt, mint távolság adatokat). Másik ellenőrzési mód a Shepard diagramm, mely a gráf éleibôl ténylegesen visszaszámított és megfigyelt utazási időket hasonlítja össze (Szökefalvi-Nagy 1972) (6. ábra). 
Legeza Enikő - Török Ádám : Európa térképe átalakul a légiközlekedés hatására.

Tér és Társadalom 23. évf. 2009/2. 225-235. p.

TÉT XXIII. évf. 2009 " 2

Kitekintö

\section{6. ÁBRA}

Shepard diagramm $\left(R^{2}=0,7658\right)$

(Shepard Diagram)

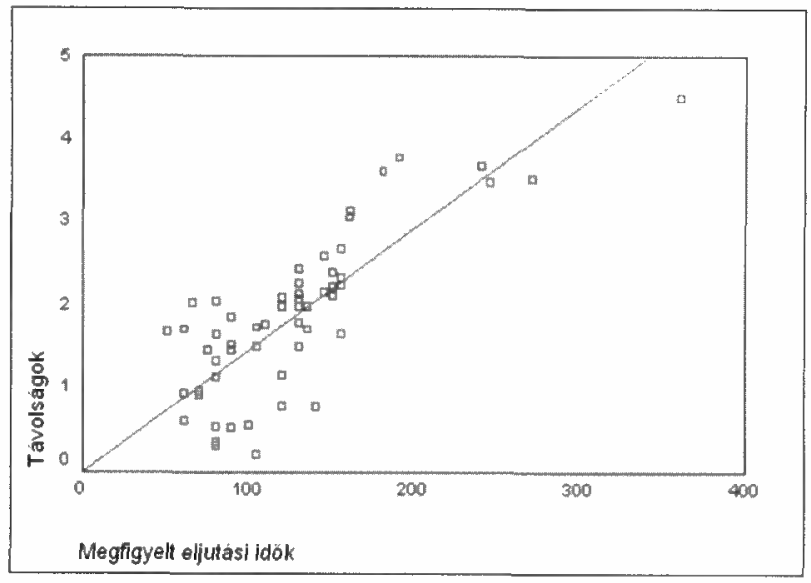

Forrás: Saját szerkesztés.

Ahogy a 6. ábrán látható, a gráf felépítése során a relatív repülótér koordináták meghatározásakor keletkezett hiba nem szignifikáns. A 6. ábrản látható folytonos monoton vonal reprezentálja a $\mathrm{f}\left(\delta_{\mathrm{ij}}\right)$ függvényét. A pontok egyenestől mért távolsága a modell tökéletlenségét jelenti. Gráfelméleti és matematikai statisztikai eszközök segítségével az utazási idő alapján meghatározott európai légikikötők új helyzete a 7. ábrán látható:

\section{7. ÁBRA}

Az utazási idők alapján készitett Európa térkép

(Map of Europe Modified by Travel Time)

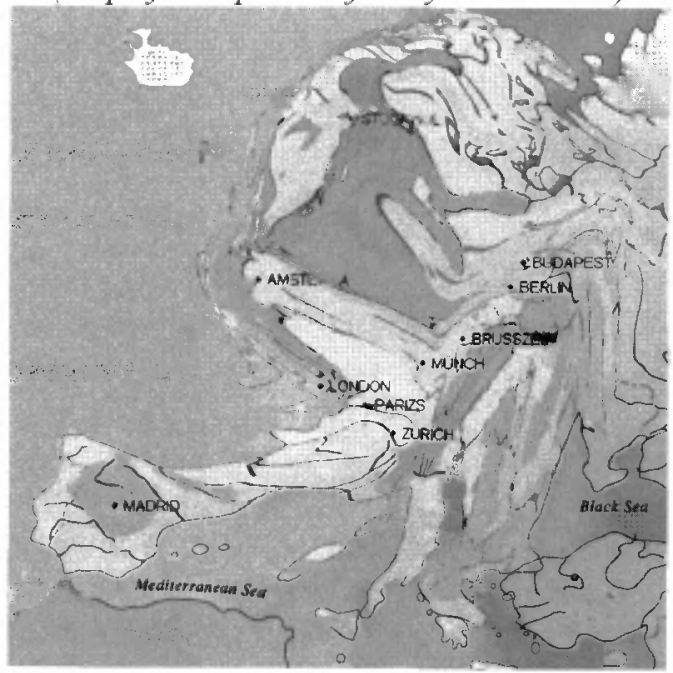

Forrás: Saját szerkesztés. 


\section{Összegzés}

Cikkünk célja a légi személy közlekedés pozitív hatásainak feltérképezése, azon belül is az utazási idő rövidülésének matematikai modellezése, megjelenítése. A szokványos két normás euklédeszi távolság használata helyett az utazási időt, mint távolság fưggvényt alkalmaztuk. Az utazási időból felépített gráf segítségével módosítottuk Európa térképét, hogy Európa legnagyobb légikikötőinek ,időbeli” helyzete transzparensebbé válhasson.

\section{TÁBLÁZAT}

Budapest reptér távolsága térben és idöben a vizsgált repterektöl (Distance and Travel Time between Budapest and the Investigated Airports)

\begin{tabular}{lclcll}
\hline & [perc] & \multicolumn{3}{c}{$[\mathrm{km}]$} & \multicolumn{2}{c}{$[\mathrm{km} / \mathrm{h}]$} \\
\hline Bécs & 60 & Bécs & 250 & Bécs & 250 \\
München & 80 & München & 600 & München & 450 \\
Berlin & 105 & Berlin & 700 & Berlin & 400 \\
Zürich & 105 & Zürich & 800 & Zürich & 457 \\
Brüsszel & 120 & Brüsszel & 1200 & Párizs & 578 \\
Amiszterdam & 120 & Amszterdam & 1200 & Brüsszel & 600 \\
Stockholm & 130 & Párizs & 1300 & Amszterdam & 600 \\
Párizs & 135 & Stockholm & 1400 & Stockholm & 646 \\
London & 150 & London & 1500 & London & 600 \\
Madrid & 190 & Madrid & 2000 & Madrid & 632 \\
\hline
\end{tabular}

Forrás: Saját szerkesztés.

Modellünk segitségével bemutattuk, hogy az európai repülöterek távolsága hogyan változik, ha földrajzi távolság helyett a repülési idöt vesszük alapul. Mindez „point to point" közvetlen utazásra vonatkozik.

\section{Jegyzetek}

${ }^{1}$ Az ortodróma valamely gömbfelület két pontja, például a föld felszínének két ponța közötti legrövidebb út.

${ }^{2}$ A loxodróma egy gömb felületére írt csavarvonal, amely a forgásfelület valamennyi alkotógörbéjével, gömbfelület esetében valamennyi délkörrel állandó szöget zár be. A földgömbre írt loxodróma a földrajzi hálózat minden meridiánját azonos szögben metszi. Ez a tulajdonsága teszi lehetôvé, hogy a jármú állandó útirányt tartva jusson a célba. 


\section{Irodalom}

Bokor Z.-Tánczos L.-né (2003) A közlekedés társadalmi költségei és azok általános és kôzlekedési módtól függó hazai sajátosságai. - Közlekedéstudományi Szemle. 8. 281-291 o.

Davies, R.E.G.-Birtles, P.J. (1999) Comet: The World's First Jet Airliner. McLean, Paladwr Press, Virginia.

Giannopoulos, G.-Aifadopoulou, G.-Torok, A. (2008) Port Choice Model for the Transshipment of Containers in Eastern Mediterranean. TRB 87th Annual Meeting, Paper \#08-1517. Washington. 25-40. o.

Kövári B. (2001) A légtér kapacitás növelésének néhány módszere, - Közlekedéstudományi Szemle. 12. 465-469. o.

Legeza E. (2001) A repülötér és környezetének kapcsolata. - Közlekedéstudományi Szemle. 7. 263-268. o.

Reinhard, D. (2005) Graph Theory. Springer-Verlag, Heidelberg, New York.

Szókefalvi-Nagy B. (1972) Valós függvények és függvénysorok. Tankönyvkiadó, Budapest. 